\title{
EFEKTIVITAS METODE TALAQQI DALAM MENINGKATKAN HAFALAN AL- QUR'AN PESERTA DIDIK DI SDIT ULUL AL-BAB WELERI
}

\author{
Leni Dwi Haryani 1)* \\ Muhtar Arifin Sholeh ${ }^{2)}$ \\ ${ }_{1}^{1}$ Program Studi Pendidikan Agama Islam, Fakultas Agama Islam \\ Universitas Islam Sultan Agung, Semarang \\ 2 Program Studi Pendidikan Agama Islam, Fakultas Agama Islam \\ Universitas Islam Sultan Agung, Semarang \\ *E-mail: leniharyani547@gmail.com
}

\begin{abstract}
The talaqqi is a method that is very suitable for beginner children especially those who cannot read well according to their lafad and makhraj. The talaqqi method is applied to make it easier for children to memorize by depositing or playing the memorization that has just been memorized to an instructor teacher to know the increase in memorization of the al-Quran. This article discusses the effectiveness of the talaqqi method in improving the memorization of al-Quran at SDIT Ulul Al-bab Weleri. The result is the implementation of the talaqqi method and the improvement of students' memorization with the highest intensity, which is very good intensity. There is a positive influence between the talaqqi method on the increase in memorization of alQuran of students There is a significant influence between the talaqqi method and the memorization of al-Quran of students in SDIT Ulul Al-bab Weleri.
\end{abstract}

Keywords: Effectiveness, Talaqqi Method, Al-Qur'an memorization

\begin{abstract}
Abstrak
Metode talaqqi merupakan metode yang sangat cocok bagi anak-anak pemula apalagi yang belum bisa membaca dengan baik sesuai lafad dan makhrajnya. Metode talaqqi diterapkan agar lebih mudah bagi anak-anak dalam menghafal dengan cara menyetorkan atau memperdengarkan hafalan yang baru dihafal kepada seorang guru instruktur untuk mengetahui peningkatan hafalan al-Quran peserta didik. Artikel ini membahas tentang efektivitas metode talaqqi dalam meningkatkan hafalan al-Quran di SDIT Ulul Al-bab Weleri. Hasilnya pelaksanaan metode talaqqi dan Peningkatan hafalan peserta didik dengan intensites tertinggi yakni intensitas sangat baik. Ada pengaruh positif antara metode talaqqi terhadap peningkatan hafalan al-Quran peserta didik Ada pengaruh yang signifikan antara metode talaqqi dengan hafalan al-Quran peserta didik di SDIT Ulul Al-bab Weleri.
\end{abstract}

Kata Kunci : Efektivitas, Metode Talaqqi, Hafalan Al-quran

\section{PENDAHULUAN}

Pendidikan Agama Islam adalah usaha untuk memperkuat iman dan ketakwaan terhadap Tuhan Yang Maha Esa, sesuai ajaran Islam, bersikap inklusif, rasional dan filosofis dalam rangka menjaga kerukunan dan kerjasama antar umat beragama (Aminudin dan aliaras 2010). Secara umum, pendidikan dapat diartikan sebagai sebuah proses belajar dengan metode-metode tertentu sehingga orang memperoleh 
pengetauhan, pemahaman, dan cara bertingkah laku sesuai dengan kebutuhan (Muhibbin, 2010).

Dalam kegiatan belajar mengajar terdapat tujuan, bahan, alat dan metode yang harus dipenuhi. Metode sebagai salah satu bagian dari keberhasilan kegiatan belajar mengajar, dalam penggunaan metode guru harus menyesukai kondisi dan suasana kelas karena, jumlah anak mempengaruhi penggunaan metode (Syaiful Bahri dan Zain, 2013).

Dalam proses pengajaran guru tidak harus terpusat pada satu metode sebaiknya menggunakan metode yang bervariasi dan menambahkan bahan ajaran lainnya seperti gambar, program televisi, film, slide, kaset audio atau kombinasi lainnya agar anak tidak merasa bosan dan jenuh (Rohani, 2015). Di samping itu guru harus menamamkan pendidikan Islam dan pendidikan al-Quran.

Hal tersebut dikarenakan pendidikan al-Quran harus ditanamkan sejak usia dini pada anak dengan menghafal, mempelajari, dan mengamalkannya. Karena al-Quran bagi umat Islam memiliki peran dan kegunaan yang amat sangat penting bagi kehidupan sehari-hari. Seperti firman Allah dalam QS. Al-qamar: 17 "dan sesungguhnya telah kami mudahkan al-Qur'an untuk pelajaran, maka adakah orang yang mengambil pelajaran?" (Massul, 2014).

Al-Quran tidak hanya dihafal, tetapi perlu disertai metode menghafal al-Quran. Metode-metode yang dianggap sesuai untuk digunakan dalam menghafal al-Quran ada 5 diantaranya: bin-nazhar, tahfidz, talaqqi, takrir dan tasmi'(Sa'dulloh, 2008).

Metode dalam proses menghafal al-Quran sangatlah penting untuk mendukung dalam mempercepat proses menghafal al-Quran. Dalam hal ini Metode yang digunakan adalah metode talaqqi karena metode ini cocok bagi anak-anak pemula apalagi yang belum bisa membaca dengan baik sesuai lafad dan makhrajnya.

Penulis menjadikan SDIT Ulul Al-bab Weleri sebagai objek penelitian karena merupakan salah satu sekolah Islam yang melaksanakan program tahfidz al-Quran pada anak sejak usia dini dibandingkan dengan sekolahan umum lainnya. Sekolah ini menerapkan metode talaqqi dalam proses belajar menghafal al-Quran agar lebih mudah bagi anak-anak dalam menghafal. Di samping itu setiap kelompok memiliki seorang guru dalam pembelajaran tahfidz al-Quran dan terciptanya lingkungan yang Islami karena selalu diputarkan murotal setiap jam istirahat. 


\section{METODE}

Untuk mendapatkan data yang diperlukan dan bisa dipertanggungjawabkan, penulis menggunakan jenis penelitian "field research". Sedangkan yeknik pengumpulan data yang digunakan yaitu penyebaran kuesioner. Selain itu juga peneliti melakukan observasi dan dokumentasi untuk mengumpulkan data sekunder, Peneliti melakukan observasi terhadap proses pengajaran, metode yang digunakan, dan kemampuan pemahaman peserta didik. Sedangkan kuesioner yang disebar digunakan untuk untuk memperoleh data mengenai:

a) Memulai dan mengakhiri pelajaran tepat waktu

b) Metode talaqqi diterapkan secara langsung face to face

c) Metode talaqqi diterapkan oleh seorang guru yang hafidz al-Quran.

d) Antara guru dan murid harus terlibat aktif dalam menghafal al-Quran.

e) Guru akan membaca atau menghafal di depan muridnya dalam rangka memberikan hafalan baru.

f) Guru akan membaca atau menghafal di depan muridnya dalam rangka memperbaiki kekeliruan ayat-ayat yang dihafal seperti pelafalan huruf-huruf, makhorijul al-huruf, waqaf, ibtida' dan lain-lain.

g) Hafalan yang masih kurang akan diperbaiki langsung oleh guru.(Qowi, 2017)

h) Ketepatan bacaan sesuai dengan tajwid

i) Kelancaraan bacaan.(Rofi, 2019)

j) Membaca secara tartil

k) Membuat target hafalan.(Sa'dulloh, 2008)

l) Memahami ayat yang telah dihafal

m) Setoran hafalan dan muroja'ah.(Massul, 2014)

Data hasil kuesioner kemudian diolah melalui hasil-hasil dari uji hipotesis. Analisis ini merupakan tahapan untuk memberi keputusan apakah ada efektivitas metode talaqqi dalam meningkatkan hafalan al-Quran peserta didik di SDIT Ulul Albab Weleri.

\section{HASIL DAN PEMBAHASAN}

Uji hipotesis pada penelitian ini menggunakan teknik analisis Regresi Linier Sederhana dengan menggunakan program SPSS versi 26. Dengan analisis korelasi Regresi Liner Sederhana didapatkan nilai t hitung ( $\mathrm{t}_{\text {hitung}}$ ) untuk mengetahui ada 
pengaruh atau tidaknya antar variabel berdasarkan data hasil penelitian diperoleh nilai t hitung (thitung) sebesar 2,566 Sedangkan nilai t tabel ( $t_{\text {tabel }}$ ) dengan $\mathrm{df}=28$ ialah sebesar 2,048 Karena nilai t hitung sebesar 2,566 nilai t tabel sebesar 2,048 sehingga dapat disimpulkan bahwa Ho ditolak dan Ha diterima, yang berarti ada pengaruh positif metode talaqqi terhadap peningkatan hafalan al-Quran. Untuk lebih jelasnya bisa dilihat pada tabel berikut:

\section{Tabel 1. Uji SPSS Regresi Linier Sederhana (metode talaqqi terhadap peningkatan hafalan al-Quran peserta didik di SDIT Ulul Al-bab Weleri )}

\section{Coefficients $^{\mathbf{a}}$}

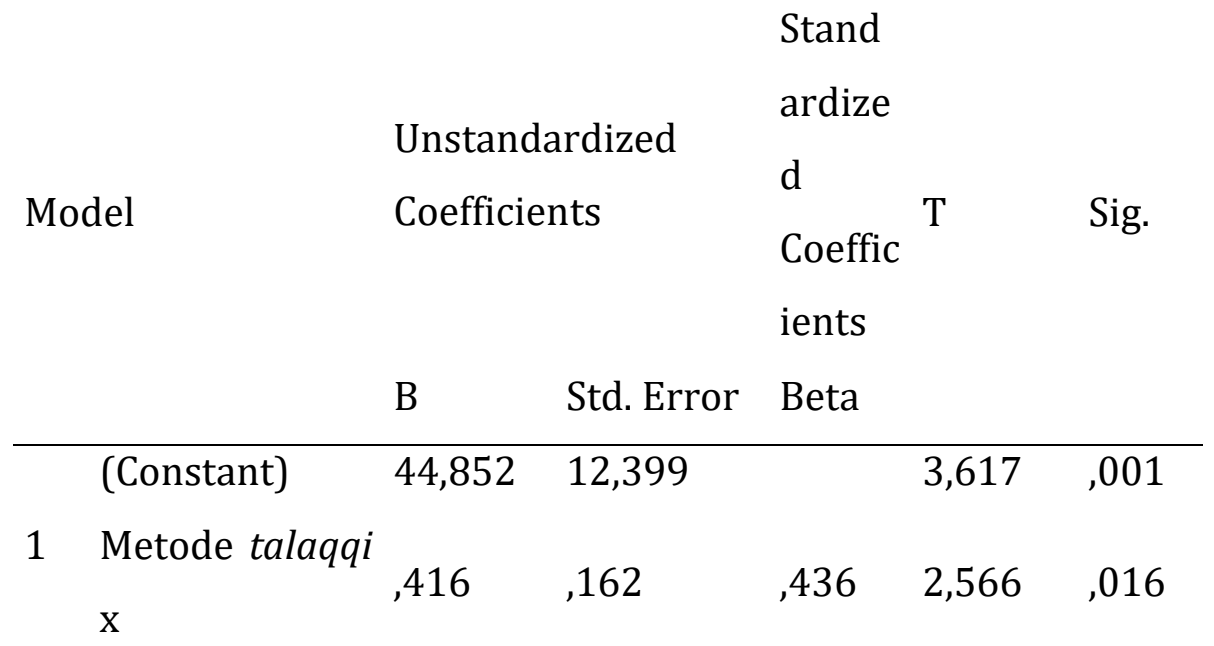

a. Dependent Variable: hafalan y

Dari hasil penelitian tabel sebesar 2,048 diperoleh thitung sebesar 2,566 dengan jumlah responden 30 peserta didik. Hal tersebut menunjukkan pengaruh positif metode talaqqi terhadap peningkatan hafalan al-Quran peserta didik di SDIT Ulul Albab Weleri. Artinya semakin baik metode talaqqi yang digunakan maka, semakin baik pula hafalan al-Qurannya. Semakin baik metode talaqqi disini adalah cara/langkahlangkahnya karena diterapkan secara langsung face to face, sehingga antara guru dan peserta didik terlibat aktif dalam proses belajar menghafal al-Quran, selain itu guru bisa memperbaiki kekeliruan ayat-ayat yang dihafal, tajwid dan makhorijul huruf secara langsung.

Dalam pembelajaran mudah mengkondisikan anak, karena dibagi dalam beberapa kelompok dan 1 kelompok 1 orang guru sehingga terdapat pengontrolan yang baik, konsentrasi anak juga terfokus pada guru karena mendengarkan bacaan guru, menirukan bersama-sama dan hafalan maju secara berurutan, dengan demikian 
guru dapat mengetahui kemampuan hafalan anak dan memperhatikan tiap anak dan pembelajaran menghafal al-Quran senin sampai kamis sehingga tiap hari mengulang hafalan dan menambah hafalan baru, dan jum'at dipakai muroja'ah.

Di samping itu, metode talaqqi meningkatkan hafalan al-Quran karena anak dituntun tiap hari menghafal dan setoran, berbeda dengan dulu tidak menggunakan metode talaqqi anak hafalan dan setoran semaunya. Baik hafalan al-Quran di sini adalah cepat menghafal, mudah menambah hafalannya, memahami ayat yang telah dihafal, ketepatan bacaan sesuai dengan tajwid, makhorijul huruf dan tartil.

Jadi dapat disimpulkan terdapat pengaruh yang penting dan tidak bisa lepas antara metode talaqqi dengan hafalan al-Quran, Sehingga terdapat peningktan hafalan al-Quran dengan menggunakan metode talaqqi dengan baik. Hasil teresbut juga diperkuat dengan didapatkan nilai signifikan sebesar 0,016<0,05, sehingga dapat disimpulkan bahwa ada pengaruh yang signifikan antara metode talaqqi dengan hafalan al-Quran di SDIT Ulul Al-bab Weleri.

\section{KESIMPULAN}

Pelaksanaan metode talaqqi dengan intensites tertinggi yakni intensitas sangat baik dengan 50\% dari 30 responden. Oleh sebab itu pelaksanaan metode talaqqi di kelas III dan IV sangat baik. Peningkatan hafalan peserta didik dengan intensites tertinggi yakni intensitas sangat baik dengan 50\% dari 30 responden. Oleh sebab itu peningkatan hafalan al-Quran peserta didik di kelas III dan IV di SDIT Ulul Al-bab Weleri adalah sangat baik.

Ada pengaruh positif antara metode talaqqi terhadap peningkatan hafalan alQuran peserta didik berdasarkan data hasil penelitian diperoleh nilai t hitung sebesar 2,566. Sedangkan nilai $t$ tabel dengan $d f=28$ sebesar 2,048. Karena nilai t hitung sebesar 2,566 $\geq$ nilai t tabel sebesar 2,048. Sehingga dapat disimpulkan bahwa Ho ditolak dan Ha diterima.

Ada pengaruh yang signifikan antara metode talaqqi dengan hafalan al-Quran peserta didik di SDIT Ulul Al-bab Weleri. Karena didapatkan nilai signifikan sebesar 0,016 $\leq$ 0,05 yang menyatakan bahwa ada pengaruh yang signifikan. Sehingga dapat disimpulkan ada pengaruh baik dan penting antara metode talaqqi dengan hafalan alQuran, Sehingga terdapat peningktan hafalan al-Quran dengan menggunakan metode talaqqi. 
52 | Leni Dwi Haryani \& Muhtar Arifin Sholeh

\section{DAFTAR PUSTAKA}

Aminudin, A., ( 2014). Pendidikan Agama Islam Untuk Perguruan Tinggi Umum, Bogor, Ghalia Indonesia.

Arikunto, S., (2010), Prosedur Penelitian Suatu Pendekatan Praktif. Jakarta: Rineka Cipta.

Emzir, (2010), Metodologi Penelitian Pendidikan Kuantitatif Dan Kualitatif. Jakarta, Raja Rgafindi Persada.

Muhibbin, S., (2010). Psikologi Pendidikan Dengan Pendekatan Baru, Bandung, PT Remaja Rosdakarya.

Massul, R., (2014). Metode Cepat Menghafal \& Memahami Ayat-ayat Suci Al-quran. Yogyakarta, Lafal Indonesia.

Qawi, A., Abdul, Peningkatan Prestasi Belajar Hafalan Al-quran Melalui Metode Talaqqi, Jurnal Ilmiah Islam Futura, vol.16. no. 2, februari 2017.

Rofi, S., (Analisis Perbedaan Hasil Belajar Siswa Mengikuti Program Tahfidz Alquran), Jurnal Pendidikan Agama Islam, vol.2 no.1 Maret 2019.

Rohani, A., (2015), Pengelolaan Pembelajaran Sebuah Pengantar Menuju Guru Profesional, Jakarta, Rineka Cipta.

Sa'dulloh, (2008). 9 Cara Praktis Menghafal Al-quran. Jakarta: Gema Insani.

syaiful Bahri Djamarah \& Aswan Zain, (2013), Strategi Belajar Mengajar, Jakarta, Rineka Cipta.

Sugiyono, (2015). Metode Penelitian Pendidikan Pendekatan Kuantitatif, Kualitatif dan $R \& D$. Bandung: Alfabeta.

Sukmadinata, ( 2012 ), Metode Penelitian Pendidikan, Bandung, Remaja Rosdakarya. 